\title{
Surface fire spread potential in trembling aspen during summer in the Boreal Forest Region of Canada
}

\author{
by Martin E. Alexander ${ }^{1}$
}

\begin{abstract}
In Canada, the importance of seasonality in forest fire danger rating associated with phenological changes in deciduous tree leaves and lesser ground vegetation has historically been taken into account by dividing the fire season into three distinct periods (i.e., spring, summer, and fall). During the mid-1980s, the developers of the Canadian Forest Fire Behavior Prediction (FBP) System did not envision that the M-2 Boreal Mixedwood - Green fuel type with $100 \%$ hardwood composition would eventually be explicitly interpreted by field users and other researchers to represent a trembling aspen (Populus tremuloides Michx.) fuel type in the summer following green-up or flushing of the overstory canopy and understory vegetation. Interest in what has become to be known as the D-2 FBP System fuel type to represent leafed-out trembling aspen stands during the summer fire season has steadily increased since. Formal recognition of such a fuel type may very well constitute an example of overextending the original basis and heuristics associated with the rate of fire spread model for the M-2 FBP System fuel type. Thus, the assumptions underlying a D-2 fuel type are explicitly restated here for the benefit of fire managers and researchers alike. Furthermore, an interim guideline is presented with respect to the threshold condition in fuel dryness necessary for surface fire spread in the D-2 fuel type to occur based on existing empirical observations garnered from experimental fires, prescribed burns and wildfires. This criterion was deduced from existing information and knowledge, and is expressed in terms of the Buildup Index (BUI) component of the Canadian Forest Fire Weather Index System. The rationale for the descriptive name assigned to the D-2 fuel type and the corresponding fuel strata characteristics are given. Improvements in the present basis of the D-2 fuel type could be realized from monitoring selected wildfires and operational prescribed fires and/or by carrying out an experimental burning study.
\end{abstract}

Key words: Canadian Forest Fire Behavior Prediction System, Canadian Forest Fire Danger Rating System, Canadian Forest Fire Weather Index System, deciduous, fire behavior, fire danger, fire environment, fire hazard, fire potential, fire risk, forest flammability, fuel type, fuel moisture, green-up, hardwood, rate of fire spread.

\section{RÉSUMÉ}

DAu Canada, limportance de lépoque de l'année dans la classification du risque de feu de forêt associée aux changements phénologiques des feuilles des feuillus et de la quantité réduite de végétation au sol ont étéhistoriquement prises en considération en divisant la saison des feux de forêt en trois périodes distinctes (c’est-à-dire, le printemps, lété et lautomne). Au cours du milieu des années 1980, les chercheurs responsables du développement de la Méthode canadienne de prévision du comportement des incendies de forêt (PCI) navaient pas envisagé que le type de combustible M-2 Peuplements nordiques mélangés comportant $100 \%$ de feuillus serait éventuellement et explicitement interprété par les utilisateurs sur le terrain et d’autres chercheurs pour représenter le type de combustible provenant des peuplements de peuplier faux-tremble (Populus tremuloides Michx.) au cours de lété après la fin de la période de feuillaison ou de lapparition du feuillage dans la cime des arbres et parmi la végétation en sous-étage. L'intérêt pour ce qui est devenu le type de combustible D-2 du Système PCI utilisé pour représenter les tremblaies en feuilles au cours de la période estivale des feux de forêt nả cessé de croître depuis lors. Une reconnaissance formelle d’un tel type de combustible pourrait très bien constituer un exemple du débordement du raisonnement et des hypothèses de base associés au modèle du taux de dispersion du feu pour le type de combustible M-2 du Système PCI. En conséquence, le texte qui suit expose explicitement les suppositions rattachées à un type de combustible D-2 pour le bénéfice des gestionnaires de feux et des chercheurs intéressés. De plus, des directives intérimaires sont présentées relativement aux conditions de base requises au niveau de l'humidité du combustible requis pour la dispersion d'un feu de surface qui pourrait survenir dans le cas d'un type de combustible D-2 à partir des observations empiriques existantes faites lors de feux expérimentaux, de brûlage contrôlé et de feux non contrôlés. Ce critère a été déduit à partir des informations et des connaissances existantes et est exprimé en tant quélément de l'Indice du combustible disponible (ICD) de la Méthode canadienne de lindice forêt météo (IFM). Le raisonnement portant sur la désignation du type de combustible D-2 et les caractéristiques correspondantes des strates de combustibles sont présentés par les auteurs. Des précisions sur la définition actuelle du type de combustible D-2 pourraient être apportées après étude d’une sélection de certains feux non contrôlés et de quelques brûlage dirigés réalisés à léchelle opérationnelle ou encore en réalisant une étude sur le brûlage à léchelle expérimentale.

Mots clés : Méthode canadienne de prévision du comportement des incendies de forêt, Méthode canadienne d'évaluation des dangers d'incendie de forêt, Méthode canadienne de l'indice forêt météo, feuillus, comportement du feu, conditions environnantes, potentiel d'incendie, risque de feu, inflammabilité des forêts, type de combustible, humidité du combustible, fin de la période de feuillaison, bois francs, vitesse de dispersion du feu

${ }^{1}$ R.P.F., Senior Fire Behavior Research Officer, Natural Resources Canada, Canadian Forest Service, Northern Forestry Centre, 5320-122 Street, Edmonton, Alberta T6H 3S5. E-mail: malexand@nrcan.gc.ca 


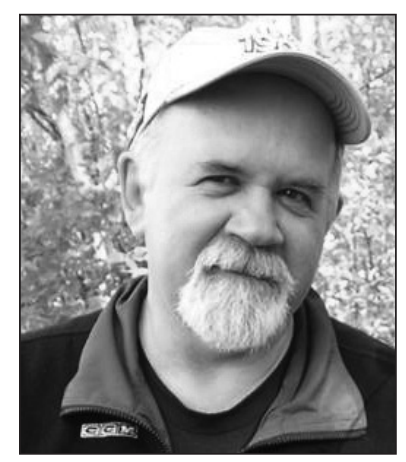

Martin E. Alexander

\section{Introduction}

The boreal forest of Canada contains mixedwood stands comprised of varying amounts of hardwood and coniferous tree species (Rowe 1972). There is considerable seasonal variation in the fire behavior potential associated with these fuel complexes, in part as a result of phenological changes in the hardwood component of the canopy and its associated understory vegetation (Fig. 1). The "condition of vegetation" is in fact considered to be one of the many variable elements of fire danger according to Brown and Davis (1973):

"The seasonal cycle has a pronounced effect on the availability of kindling fuels. Whether grass, weeds, ferns, brush, or other foliage fuels are green, curing, or dry has tremendous effect on both the quantity and flammability of such fuels. In hardwood types, whether the leaves are green on the trees or dead on the ground can spell the difference between very little and high fuel hazard."

In their early work on fire danger rating in Canada, Wright and Beall (1938) pointed out that the fire potential in hardwood forests "... is very much higher during those parts of the spring and fall when the leaf canopy is absent or incomplete than it is during the intervening months in the summer. The fire season is therefore divided into three periods - spring, summer and fall ..." and the same applied to the mixedwood type (Table 1). This distinction was recognized in all subsequent fire danger rating tables produced in Canada (e.g., Kiil and Quintilio 1969) up to the release of the Canadian Forest Fire Weather Index (FWI) System (Van Wagner 1987) in 1970 and in various Canadian fuel type and fire hazard classifications schemes. Simard et al. (1989) were able to develop a weatherbased model for predicting green-up and transitions between seasonal periods.

While fires in certain hardwood forests of western and northern North America are expected to occur during the spring and fall of the year, the probability of their occurrence during the summer months has in the past generally been
Table 1. Criteria for distinguishing the three periods of the fire season for fire danger rating purposes at the Petawawa Forest Experiment Station near Chalk River, Ontario, during the late 1930s (adapted from Wright and Beall 1938).

\begin{tabular}{ll}
$\begin{array}{l}\text { Fire season } \\
\text { period }\end{array}$ & Description of criteria \\
\hline Spring & $\begin{array}{l}\text { Lasts until the first rain of } 13 \mathrm{~mm}(0.5 \mathrm{in} \text {.) or more } \\
\text { has fallen after the leaves of the tree crowns are one- } \\
\text { half developed. If such a rain does not fall until the } \\
\text { leaves are fully developed, the first rain of } 6 \mathrm{~mm} \\
\text { (0.25 in.) or more, after full leaf development, ends } \\
\text { the spring fire season. On the average, the hardwood }\end{array}$ \\
& $\begin{array}{l}\text { leaves are one-half developed about May } 25 \text {, and are } \\
\text { fully developed by about June } 2 .\end{array}$ \\
Summer & $\begin{array}{l}\text { Between the end of the Spring period as described } \\
\text { above and the beginning of the Fall period as } \\
\text { described below. } \\
\text { Begins when one-third of the leaves of the tree } \\
\text { crowns have fallen. This occurs approximately } \\
\text { October } 8 .\end{array}$
\end{tabular}

Note: Kiil and Quintilio (1969) regarded the change from spring to summer period in Alberta to occur when (a) the first rain of $6 \mathrm{~mm}$ ( $0.25 \mathrm{in}$.) or more falls after the leaves are fully developed on poplars and birches or (b) 2 weeks after the leaves are fully developed if no rain of as much as $6 \mathrm{~mm}(0.25 \mathrm{in}$.) has fallen during that time. The change from summer to fall period occurs when one-quarter of the leaves on the poplars and birches have fallen.

regarded as unlikely. The live trembling or quaking aspen (Populus tremuloides Michx.) stand type in the Rocky Mountains, for example, has been described as an "asbestos forest" because it does not commonly exhibit the extreme fire behavior usually characteristic of coniferous forests during the summer fire season (Wright and Bailey 1982). DeByle et al. (1987) report that wildfires burning in coniferous and shrubland fuel complexes under extreme weather conditions in the western U.S. seldom penetrate pure aspen stands by more than $30 \mathrm{~m}$.

In the boreal forest of Canada, trembling aspen stands have traditionally been regarded as barriers to fire spread during the summer fire season. However, in response to changing climatic and perhaps fuel conditions (Amiro et al. 2001), the incidence of wildfires spreading in northern hardwood forests may be more commonplace. de Groot et al. (2009), for example, have documented the occurrence of wildfire activity in trembling aspen forests in central Saskatchewan in early

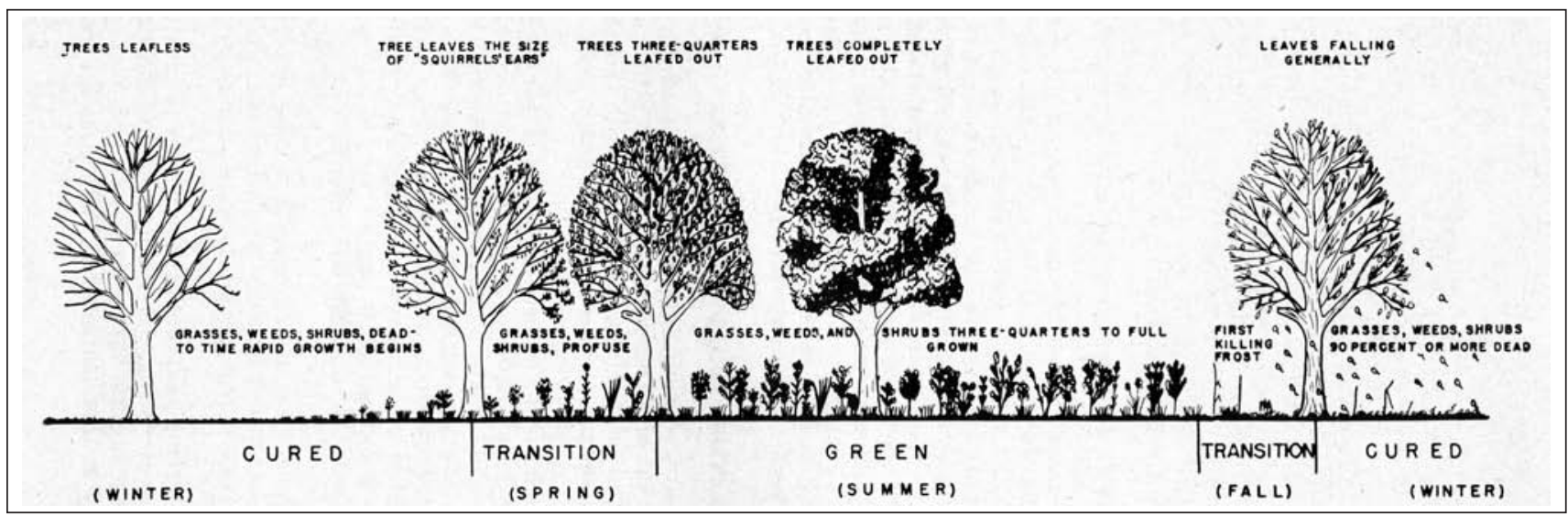

Fig. 1. A classification scheme for condition of lesser vegetation in hardwood stands used in forest fire danger rating during the 1950 s and early '60s in the eastern United States (from Jemison et al. 1949). 
August 2003 and similarly in the southeastern region of the Yukon Territory in early July 2004. As a result, there has been a growing interest within the Canadian wildland fire community, particularly amongst those engaged in simulating fire impacts and effects at the landscape-scale level and in developing computerized decision support systems, to officially recognize the existence of a D-2 fuel type (to represent trembling aspen stands following "green-up" in summer) in the Canadian Forest Fire Behavior Prediction (FBP) System (Forestry Canada Fire Danger Group 1992, Taylor et al. 1997). Such a capability will enable managers to develop more effective fire and fuel management strategies.

The purpose of this paper is to formally establish the basis for the FBP System D-2 fuel type and its usage, as initially discussed in Wotton et al. (2009, p. 29). Some general familiarity with the FBP System and the FWI System (Van Wagner 1987) on the part of the reader is presumed.

\section{Seasonal Changes in the Flammability of Northern Hardwood Forests}

Here we review the dynamic changes in the fuel complex characteristics and microclimatic conditions associated with the seasonal flammability in northern hardwood forest stands such as the trembling aspen type (Fig. 2). Fires in live hardwood stands in the summer are generally of low-intensity. In this regard, Stickel (1931) said of hardwood forests in upstate New York:

"In the Adirondacks, where forests have a decided seasonal aspect when the hardwood foliage is present or absent, the forest canopy plays a remarkable role in reducing the fire hazard. The end of spring and the beginning of the fall fire seasons are determined largely by the appearance and disappearance of the hardwood foliage. While the hardwood trees are in leaf they protect the duff from all the drying effects of weather to such an extent that a hazard seldom exists in the green timber."

Haines et al. (1986) have noted that throughout the northeastern U.S. in general, "When fuels are green ... their moisture content may be so high as to overwhelm environmental conditions and preclude wildfire occurrence. ... In this situation, living vegetation may be like a switch that turns fires on and off rather than a heat sink that reduces spread rates and intensities."

On the subject of seasonality and forest fire danger, Wright and Beall (1934) have stated that: "The month of May is recognized by foresters in eastern Canada as constituting a particularly dangerous period from the standpoint of fire hazard. It comprises the greater part of that critical stage between the melting of snow in the woods and the development of herbaceous plants, ground vegetation, and the foliage of shrubs and trees. A somewhat similar situation occurs in the late fall, after the death of seasonal vegetation, although possibly mitigated to some extent by the shortened hours of daylight."

Certainly the same can be said for the boreal hardwood forests of western Canada (Kiil and Grigel 1969, Kiil and Quintilio 1969, Kiil et al. 1977). However, a case could easily be made that in the autumn following leaf fall, an equally or more hazardous period can exist in some areas if preceded by a severe summer drought (Haines and Sando 1969, Haines et al. 1976). Such a case occurred in the hardwood forests of northern Maine in late October 1947 (Butler 1997)2.
Hardwood forests are devoid of foliage in the spring and late fall (Sayn-Wittgenstein 1978). Full green-up or flushing of the leaf foliage in the overstory tree canopy and the understory vegetation layer in late spring/early summer has a pronounced effect on the microclimatic conditions in a northern hardwood stand and hence on forest fuel flammability (Fig. 2). Wright and Beall (1938) noted that "... a longer stretch of dry weather is required for a hazard to develop during late summer than in early summer." Consider the following changes that occur in the fire environment of a northern hardwood forest stand as the fuel complex transitions from a "cured" state in the spring following snow melt to full greenup at the start of the summer period:

- A reduction in the effective in-stand wind speed at the ground level which in turn influences fine fuel drying and the direct affects of air flow on the flame front propagation (Marston 1956, Frederick 1961).

- An increase in shading as a result of the leafy canopy and lower vegetation (Kiil et al. 1977) and thus a decrease in direct effects of solar radiation on the surface litter leads to lower fuel temperatures and decreased drying in the leaf litter (Byram and Jemison 1943, Van Wagner 1969).

- A decrease in air temperature and an increase in the relative humidity of the in-stand conditions results in decreased drying potential of the fine, surface fuels (Wright and Beall 1934).

- The surface leaf litter becomes matted and more compacted (Van Wagner 1983).

- The reduction in solar radiation at the ground surface coupled with the changes in weather elements leads to substantially less drying in the litter and duff layers (Van Wagner 1970, Wotton and Beverly 2007).

- The "green surface fuel effect" (Van Wagner 1975) resulting from the appearance of the understory vegetation with its very high $(>100 \%)$ moisture content (Loomis et al. 1979, Brown et al. 1989) causes a dampening influence on surface fire spread.

- The crown fuels of the overstory will not support crown fire, presumably in part because of the very high $(>140 \%)$ moisture content of the foliage (Van Wagner 1967, 1977) and low quantities of fine, dead twigs and branchwood (Loomis and Roussopoulos 1978).

Interestingly, Beall (1934) found that there was not a great deal of difference in the percentage of rainfall reaching the forest floor as a result of the presence of the hardwood foliage in summer compared to the leafless state in the spring. Dunne and Leopold (1978) report a median canopy interception rate of $13 \%$ for deciduous forests.

Wright and Beall (1934) sum up the combined consequences of the changes described above:

"The results of all these factors in the hardwood stand ... is that within a period of about three weeks this forest type is transformed from one of the most hazardous areas ... to one in which it is almost impossible to start a fire under any circumstances."

These changes that occur in the tree canopy and lower

${ }^{2}$ At the time of these devastating fires, the Duff Moisture Code (DMC), Drought Code (DC) and Buildup Index (BUI) components of the FWI System at Portland, Maine, had reached levels of around 90, 500, and 125, respectively (Alexander 2004). 

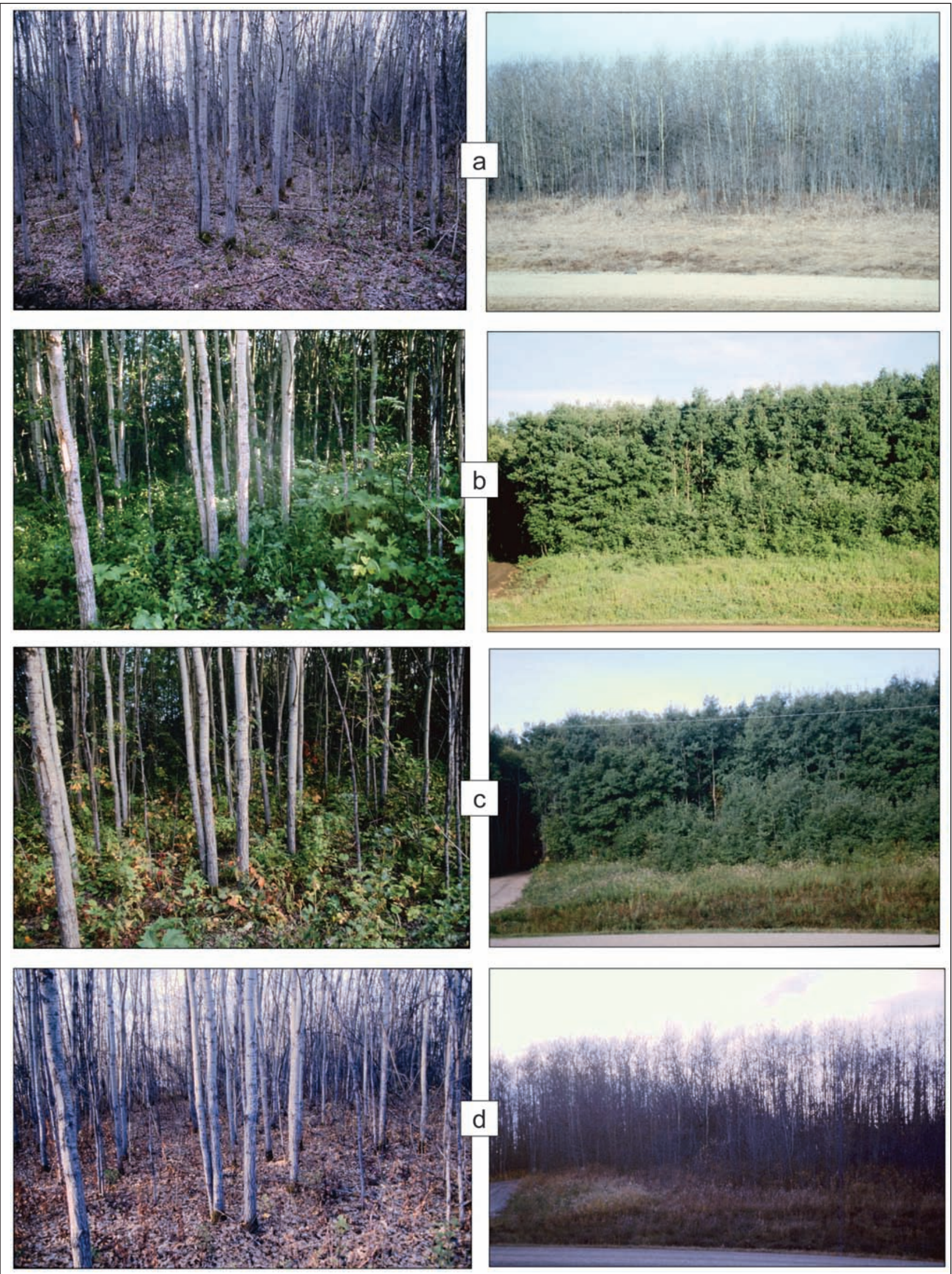

Fig. 2. Visual depiction of the seasonal changes in the overstory and understory of a semi-mature trembling aspen stand in central Alberta following snow-free cover in the spring, through the summer, and up to mid-autumn: (a) April 26, (b) June 30, (c) September 7, and October 18, 1994. 


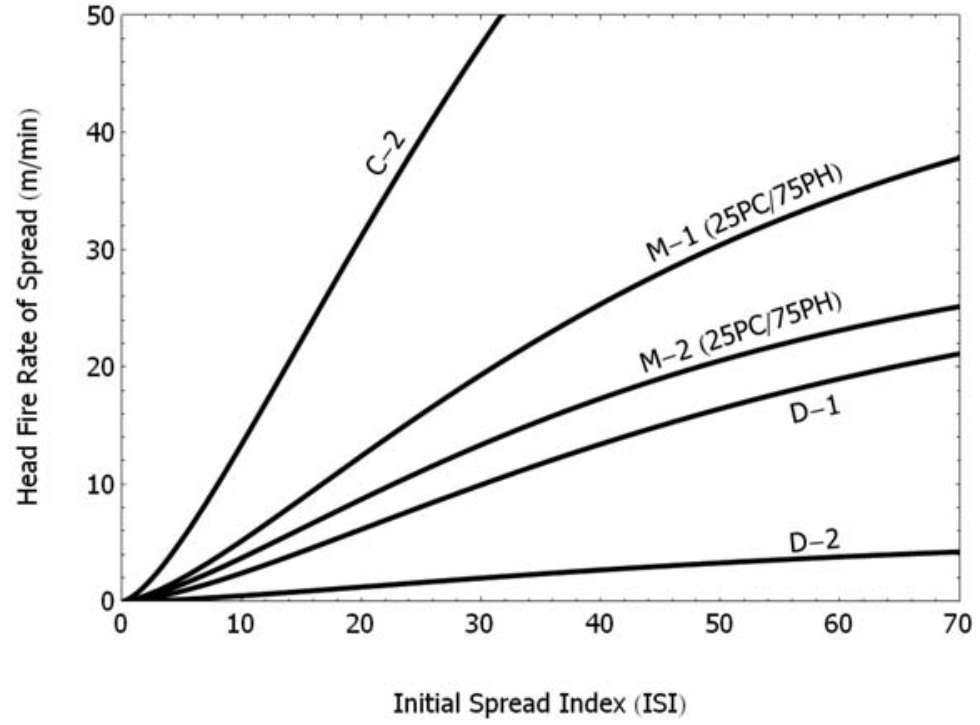

Fig. 3. Equilibrium head fire rate of spread (ROS) on level terrain as a function of the Initial Spread Index (ISI) component of the Canadian Forest Fire Weather Index (FWI) System for the Boreal Spruce (C-2), Boreal Mixedwood - Leafless (M-1), Boreal Mixedwood - Green (M-2), and Leafless Aspen (D-1) fuel types in the Canadian Forest Fire Behavior (FBP) Prediction System according to Forestry Canada Fire Danger Group (1992) in relation to the Green Aspen (D-2) fuel type. Both of the boreal mixedwood fuel types contained 25 percent conifer (PC) and 75 percent hardwood (PH). The Buildup Index (BUI) component of the FWI System was set at 70 for the purpose of the buildup effect adjustment on ROS found in the FBP System.

1970), no empirical data on fire behavior (e.g., rate of spread) in natural boreal mixedwood forest stands in Canada existed at the time. Given the preponderance of mixedwood stands in the boreal and other forest regions of Canada, an alternative solution was devised in the development of the interim edition of the Canadian Forest Fire Behavior Prediction (FBP) System (Lawson et al. 1985). This involved an approach similar to the "two fuel model concept" of Rothermel (1983, p. 12). The primary assumption made is that within a given boreal mixedwood stand or designated fuel type polygon, the fire spread rate will vary according to the proportional area occupied by the coniferous versus the hardwood component of the stand. This approach was retained in the first complete edition of the FBP System (Forestry Canada Fire Danger Group 1992).

The FBP System currently recognizes two healthy boreal

vegetation in northern hardwood forests create conditions that reduce the probabilities of fire ignition and spread as evident in the reduction in wildfire occurrences and area burned in areas dominated by such fuel types in eastern (Wein and Moore 1977) and western Canada (Cumming 2001, Tymstra et al. 2005, Krawchuk et al. 2006) as well as the northeastern and north-central U.S. (Haines et al. 1970, 1973, 1975, 1978).

\section{Basis for the Existence of a D-2 Fuel Type}

In the FBP System, the primary independent variable influencing the equilibrium head fire rate of spread (ROS) on level terrain is the Initial Spread Index (ISI) component of the FWI System (Fig. 3); the resultant spread rate can be adjusted for the mechanical effects of slope. The ISI is a relative numerical rating of the expected rate of fire spread. It combines the effects of wind and the Fine Fuel Moisture Code (FFMC) without the influence of variable quantities of fuel, which is accounted for in the FBP System by an adjustment factor based on the Buildup Index (BUI) component of the FWI System. The BUI is a compound measure of the Duff Moisture Code (DMC) and Drought Code (DC) that indicates the total amount of fuel available for combustion (Van Wagner 1987). The DMC and DC are numerical ratings of the average moisture content of (i) loosely compacted organic layers of moderate depth, and (ii) deep, compact, organic layers, respectively.

Some experimental burning has been carried out in boreal mixedwood stands following partial cutting (e.g., Tucker and Jarvis 1967, Alexander 1982). However, other than the Canadian Forest Service (CFS) 2-minute test fire database involving small-scale, point source ignitions (Paul 1969, Simard mixedwood types - i.e., Boreal Mixedwood - Leafless (M-1) and Boreal Mixedwood - Green (M-2). The ROS equations for these two fuel types are just the sums of the ROS equations for the Boreal Spruce (C-2) and Leafless Aspen (D-1) types weighted by the percent conifer (PC) and percent hardwood $(\mathrm{PH})$ composition (Fig. 3). In practice, combinations are commonly employed (e.g., 75PC/25PH, 50PC/50PH, and $25 \mathrm{PC} / 75 \mathrm{PH}$ ) as given for example in the FBP System field guide (Taylor et al. 1997) and as illustrated to a small extent in Fig. 3. The PC and PH combination must total 100.

The general form of the ROS equation for fuel type M-1 is as follows:

$$
\begin{aligned}
\text { [1] } & \operatorname{ROS}_{\mathrm{M}-1}=\left([\mathrm{PC} / 100] \times \mathrm{ROS}_{\mathrm{C}-2}\right)+ \\
& \left([\mathrm{PH} / 100] \times \mathrm{ROS}_{\mathrm{D}-1}\right)
\end{aligned}
$$

In turn, the general form of the ROS equation for fuel type M-2 is as follows:

$$
\text { [2] } \begin{aligned}
\operatorname{ROS}_{\mathrm{M}-2}= & \left([\mathrm{PC} / 100] \times \mathrm{ROS}_{\mathrm{C}-2}\right)+0.2 \times \\
& \left([\mathrm{PH} / 100] \times \mathrm{ROS}_{\mathrm{D}-1}\right)
\end{aligned}
$$

The above equation for fuel type M-2 is similar to that of fuel type M-1 except that the hardwood or D-1 component of equation [1] is multiplied by a factor of 0.2. This approach was taken because no empirical rate of fire spread data for hardwood fuel types under summertime or leafed-out situations existed at the time the FBP System was initially developed, only leafless or springtime and fall conditions (Alexander and Maffey 1992-93). It was therefore assumed, based on 
the collective opinion of the CFS Fire Danger Group at the time, that the rate of fire spread in summer following green-up of the overstory and understory in the D-1 fuel type was $20 \%$ of the leafless state that occurs in the spring and fall for a given set of burning conditions (Lawson et al. $1985)^{3}$. The fire spread potential in trembling aspen in summer suggested by this heuristic gradually became accepted as fact in some circles (e.g., Johnson 1992, p. 30).

The 0.2 multiplier presented in equation [2], produced the desired end result sought by the developers of the FBP System, namely a relatively lower spread rate in stands with a very high hardwood component. For example, an average BUI level of 32 would yield a head fire rate of spread of less than $2 \mathrm{~m} / \mathrm{min}$ at an ISI of 30 compared to $10 \mathrm{~m} / \mathrm{min}$ in the D-1 fuel type (Fig. 3) ${ }^{4}$. As Wotton et al. (2009) have pointed out, "This relatively conservative approach ... was justified on the grounds that fire spread in hardwood stands in summer is indeed considered possible on the basis of past experimentation ... and numerous informal observations and anecdotal accounts of wildfires burning in mixedwood stands of varying conifer and hardwood composition during the summer." It also reflects the "art" that is sometimes required in not only applying models for predicting wildland fire behavior but in developing them (Van Wagner 1985).

Some users of the FBP System (e.g., Parisien et al. 2005a, 2005b, 2007; Williamson et al. 2008; Beverly et al. 2009; Tymstra et al. 2009), have assumed that a D-2 fuel type effectively

\footnotetext{
${ }^{3}$ Complete green-up in trembling aspen stands does not always follow conventional patterns. During a dry, warm spring, the aspen overstory will flush but flushing of the understory is delayed until substantial precipitation occurs, and this is even more prevalent in trembling aspen stands with significant quantities of cured grass. This delayed green-up phenomenon in the understory vegetation was observed in trembling aspen stands while serving as the fire behavior specialist on the incident management team assigned to the 170 000-ha Virginia Hills Fire near Whitecourt, Alberta, in May 1998. This presumably also occurred on the 2001 Chisholm Fire in central Alberta (Quintilio et al. 2001) and in other areas of the western Canadian boreal forest (M. Heathcott, Parks Canada, Calgary, $\mathrm{AB}, 2009$, personal communication). When this occurs, it is better to use fuel type D-1 and reduce the 10-m open wind speed input in the calculation of the ISI to account for the reduction in effective wind due to the presence of the canopy leaf foliage. Depending on the amount of grass present, it may be necessary to apply one of the FBP System grass fuel types (O-1a or O-1b), including an assessment of the degree of curing, in place of the D-1 fuel type and reduce the effective wind speed to account for the overstory canopy accordingly. ${ }^{4}$ For a perspective on these burning conditions, an ISI of 30 and a BUI 32 could occur, for example, following a dry spell of 7 to 10 days after snow-free cover in the spring, with an air temperature $\left({ }^{\circ} \mathrm{C}\right)>$ relative humidity $(\%)$, and $10-\mathrm{m}$ winds of 30 to $35 \mathrm{~km} / \mathrm{h}$.
}

exists as a result of being able to set $\mathrm{PC}=0$ and $\mathrm{PH}=100$ in equation [2] for the M-2 fuel type. In other words, the general form of the ROS equation for a D-2 fuel type would simplify to:

$$
\text { [3] } \operatorname{ROS}_{\mathrm{D}-2}=0.2 \times \mathrm{ROS}_{\mathrm{D}-1}
$$

As suggested by the 0.2 constant in equation [3], presumably once a leafless trembling aspen stand has completely made the transition from spring to summertime conditions, all of the seasonal changes in fuel and microclimatic conditions as described earlier result in an $80 \%$ reduction in the potential surface rate of fire spread (Fig. 3).

Limited evaluations of equation [1] have so far been encouraging (Stocks 1988, Hély et al. 2001). No formal evaluation of equations [2] or [3] has been undertaken to date. Short of carrying out experimental fires in trembling aspen stands in the middle of summer, is there any means of gauging whether equation [3] is reasonably valid? It is highly unlikely that this question can be realistically tackled by theoretical means using laboratory test fires (e.g., Dickinson and Johnson 2003) for instance, given the inherent complexities associated with the mixtures of live and dead surface fuels and the gradients in moisture and bulk density through the forest floor profile (Van Wagner 1979, 1985).

One might consider using the dynamic fuel models developed for western aspen stands by Brown and Simmerman (1986) in the context of the BehavePlus modelling system (Andrews et al. 2008). However, Hély et al. (2001) found that BehavePlus performed rather poorly against experimental fires carried out in boreal mixedwood stands that contained high amounts of hardwood.

In formally recognizing the existence of a D-2 fuel type in the FBP System, identifying when one can expect equation [3] to apply is probably far more important that precisely pre- 
dicting the fire spread rate. At a BUI of 200 and ISI of 70, representing exceedingly explosive burning conditions, the predicted head fire rate of spread in fuel type D-2 is less than $5 \mathrm{~m} / \mathrm{min}$ (Taylor et al. 1997).

\section{Establishing a Threshold Burning Condition for the D-2 Fuel Type}

Are there other factors that need to be considered in determining the potential for fire spread in a trembling aspen fuel type during the summer fire season? The comments of Stickel (1931), Wright and Beall (1934) and Haines et al. (1986) suggest that some threshold value in burning conditions must be exceeded before fire spread in a hardwood stand in summer is possible.

The author has lived on a trembling aspen acreage (Fig. 2) located in the B.18a - Mixedwood Forest Section of the boreal forest (Rowe 1972) in central Alberta about $15 \mathrm{~km}$ northeast of the city of Leduc for the past 15 years. As a rural homeowner and also as a part-time, volunteer fire guardian for the County of Leduc Fire Services for nearly the same period of time, there have been many occasions to contemplate the possibility of fire spread in pure trembling aspen stands under summertime conditions. One particular point in time stands out: during the summer of 2002 when there was an extended dry spell early in the fire season (Fig. 4). The understory shrubs were noticeably stressed and changing color (i.e., yellowing) by mid-July and they appeared to be on the verge of wilting before several significant rains occurred. In early July of that same year, the DMC peaked at about 90 and the DC was approximately 625 at the main fire weather station in Elk Island National Park east of Edmonton (Otway 2005), which equates to a BUI of 132. On July 8,2002 , mineral soil moisture contents of $15 \%$ to $20 \%$ were registered at a depth of $11 \mathrm{~cm}$ in a mature trembling aspen stand adjacent to the park's weather station (S. Otway, Parks Canada, Jasper, AB, 2009, personal communication ).

Wotton et al. (2009) have suggested that in addition to the surface fuels being sufficiently dry, the duff moisture content would have had to reach some minimum value for fire spread to be possible in a D-2 fuel type. At a CFS fire research meeting held in Edmonton in May 2000, the statement was made to the gathering that in order for a D-2 fuel type to exist in the form of equation [3], it would have to be qualified in some manner in terms of the BUI. For instance, equation [3] would only apply when the BUI exceeded some critical value like 80, for example. This suggested example eventually became coded into computerized decision support systems such as Prometheus (Tymstra et al. 2009) and in turn Burn-P3 (Parisien et al. 2005b) but not the Spatial Fire Management System (Lee et al. 2002; P. Englefield, Canadian Forest Service, Edmonton, $\mathrm{AB}, 2009$, personal communication ).

What empirical data or information is available by which to deduce a threshold value in terms of the BUI? What follows is a summary of the available qualitative and quantitative information available from experimental fires, prescribed burns and wildfires that might help to answer this question.

Otway et al. (2007a) investigated the potential for sustained smouldering ignition in trembling aspen stands in Elk Island National Park in central Alberta using outdoor field trials carried out through the entire fire season. They found that the $50 \%$ probability level for sustained smouldering combustion in the duff layer occurred at a DMC of 27 and a DC of 300 , equating to a BUI of 44 . The requirements for near certainty ( $100 \%$ probability) in ground or subsurface fire persistence would be a DMC of $\sim 70$ and DC of $\sim 500$. This equates to a BUI of 104. The answer to defining a fuel dryness threshold undoubtedly lies somewhere between these two situations.

During the International Crown Fire Modelling Experiment (ICFME) carried out near the community of Fort Providence, Northwest Territories (Stocks et al. 2004), a crown fire initiated in the jack pine (Pinus banksiana Lamb.) - black spruce (Picea mariana [Mill.] BSP) portion of the experimental plot failed to sustain itself upon meeting a fully leafed out trembling aspen stand with a shallow forest floor layer and minimal amounts of understory vegetation (Alexander and Lanoville 2004). The experimental fire was carried out on June 17, 1999 in a plot measuring $150 \times 150 \mathrm{~m}$ in size (Fig. 5). The prevailing burning conditions were considered extreme (Table 2), although surface fire spread was sporadic upon entering the aspen portion of the plot, initially displaying very low, open flames and finally fading to smouldering combustion.

Additional information exists from experimental burning conducted in the Caribou-Poker Creeks Research Watershed located northwest of Fairbanks, Alaska. The FROSTFIRE landscape-scale prescribed fire was carried out July 8 to 10 , 1999 and involved an area of 970 ha (Hinzman et al. 2003, Rorig et al. 2003). The fire weather and fire danger conditions over the three days of active burning are summarized in Table 2. According to Hinzman et al. (2003) only about one-third of the area eventually burned, and "the majority of the relatively flammable black spruce vegetation burned, whereas the less flammable deciduous birch and aspen stands and the wetter Sphagnum-dominated valley bottoms did not burn."

From a wildfire perspective, high-intensity fire behavior was observed in a mature aspen forest following green-up during the major wind-driven, upslope $(\sim 30 \%)$ run of the Rosie Creek Fire into the Bonanza Creek Experimental Forest 

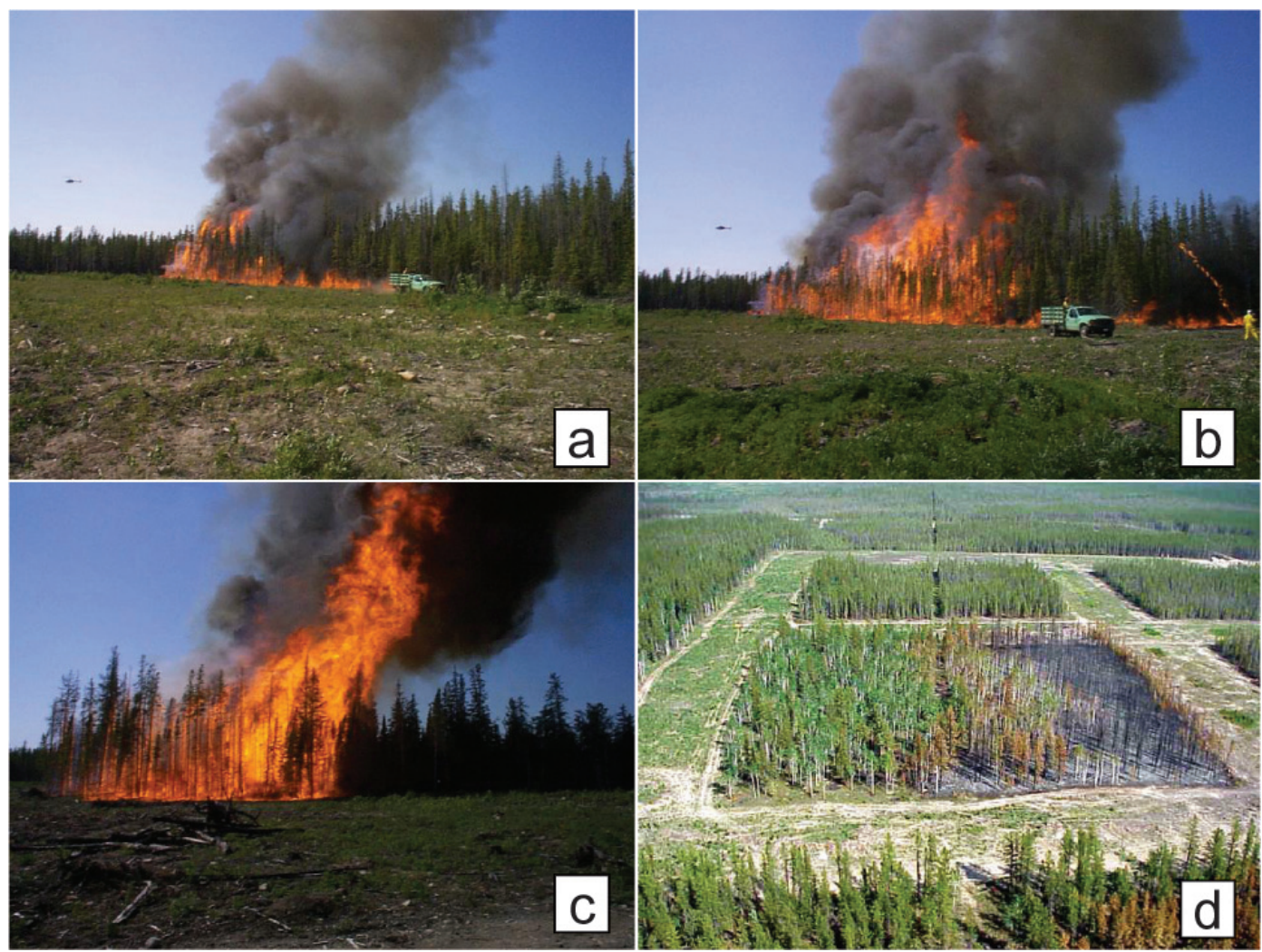

Fig. 5. Ground views of an experimental crown fire in a mixed jack pine - black spruce - trembling aspen plot (a-b) following ignition, (c) during the period of active burning, and (d) an aerial post-burn view. The high-intensity flame front associated with the onset of crowning in the conifer component of the plot following ignition of the plot edge failed to sustain itself upon entering the leafed-out hardwood portion of the plot.
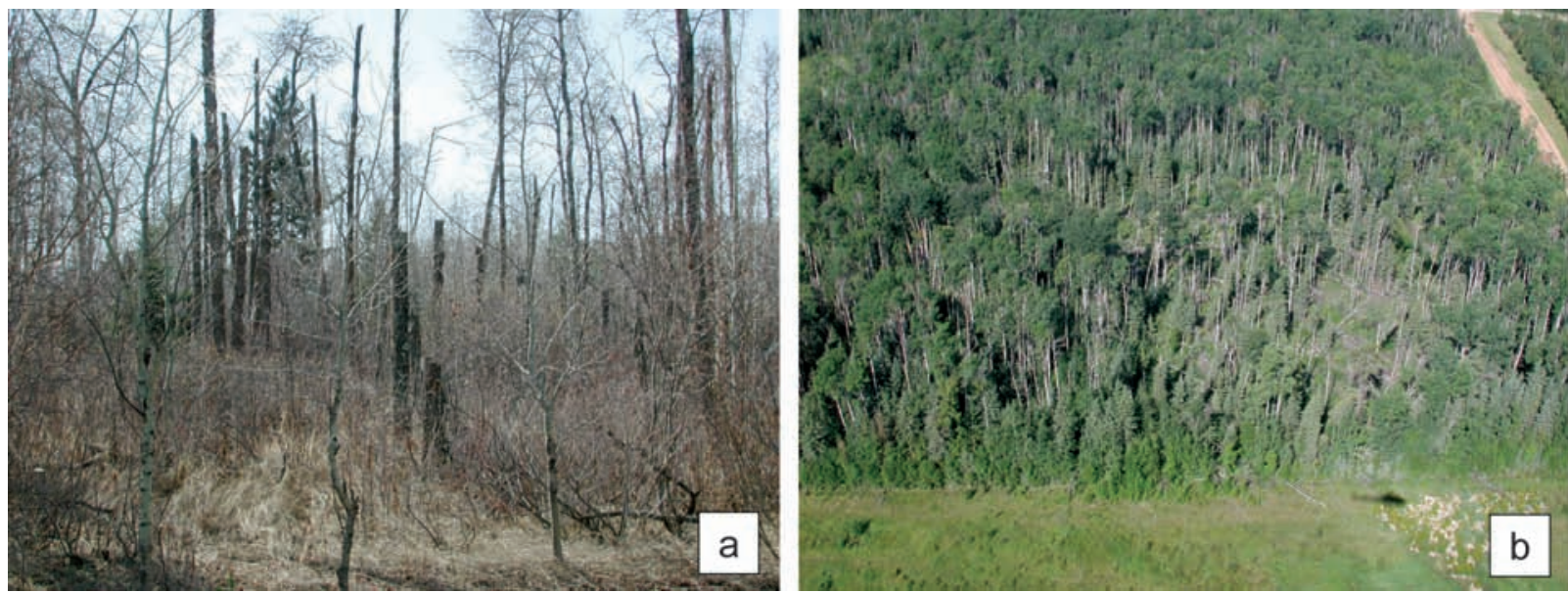

Fig. 6. Overmature trembling aspen stands in central Alberta in (a) the leafless state in the spring and (b) following leaf-out in the summer. High fireline intensities can be expected in the spring due to the heavy dead-down woody fuel accumulations coupled with old grass mats both of which greatly increase the resistance to fireguard construction regardless of the season. Dead trees or snags readily contribute to spot fire development. Photos by W. Bereska, Wildfire Consulting Ltd., Edmonton, AB. 
near Fairbanks, Alaska, on June 2, 1983 (Juday 1985). Burning conditions reported at the nearby international airport weather station $(\sim 20 \mathrm{~km}$ away) were relatively severe (Alexander and Cole 1995). For that time of year, the DMC and DC levels reflect a relatively warm and extended dry spell following snow melt in the spring (Table 2).

Beverly and Wotton (2007) re-analyzed some of the data on the 2-minute test fires carried out in different fuel types by the federal forest service fire research group (Paul 1969, Simard 1970) in the late 1950s and early 1960s for the purposes of developing regional fire danger rating tables (e.g., Kiil and Mactavish 1962). This included an "aspen leaf (summer)" site near Fort Smith, Northwest Territories, described as a "Pure, 60-year old even-aged trembling aspen stand with a basal area of $\sim 22 \mathrm{~m}^{2}$ per hectare. During the summer months there is dense minor vegetation cover consisting of clumps of Salix spp., Shepherdia spp. and Rose (Rosa spp.) bushes. Underneath this shrub layer is a fairly complete cover of "various herbaceous plants. During the summer of 1961, a total of 131 test fires were attempted in the aspen stand between June 9 and August 30. Sustained flaming combustion in surface fuels following a single match ignition in the leaf litter was achieved in 30 such cases. The mean BUI value associated with these sustained flaming ignitions was 106 and ranged from 73 to 138 based on an analysis of the raw data which was kindly provided by J. Beverly (Canadian Forest Service, Edmonton, $\mathrm{AB}, 2009$, personal communication ).

The other 71 test fire attempts either did not result in an immediate ignition or failed to sustain themselves beyond two minutes. This included test fire ignition trials at BUI values in the range of 29 to 69 . Unfortunately, surface fuel conditions were not conducive to fire spread in order to examine the influence of the BUI at values below 73. The leaf litter moisture contents were inevitably too high (e.g., >20\%) or not nearly low enough to overcome the "heat sink" effect associated with the green understory vegetation to support spreading combustion in the surface fuels.

It should be clear from the preceding accounts that the data that are readily defining a threshold condition for surface fire spread in the D-2 fuel type in terms of fuel dryness are somewhat noisy. This is no doubt a reflection of the differences in physiographic site, stand structure and composition, fuel, and minor vegetation characteristics amongst the experimental, prescribed, and wild-fire observations ${ }^{5}$. However, on the basis of the information as presented and discussed here, setting the threshold for surface fire spread for the D-2 fuel type at a BUI of at least 70, at least for interim purposes, would be reasonably valid. In reaching this recommendation, it is readily acknowledged that the threshold value could conceivably be higher in other forest regions of Canada where the D-2 fuel type would be applied, especially in temperate hardwood forests. For example, in shade-tolerant hardwood stands, such as sugar maple (Acer saccharum Marsh.) found in the Great Lakes - St. Lawrence Forest Region of eastern Canada, where forest floor layers and surface fuel loads are not nearly as great as those in trembling aspen stands of the

\footnotetext{
${ }^{5}$ The importance of elevation, slope exposure or aspect, climate, soil attributes, moisture regime, drainage, and toposequence or catena (Weil 2003) to fuel moisture and fire potential in general, as demonstrated, for example, by Otway et al. (2007b) cannot be overlooked.
}

boreal forest (M. Theriault, Parks Canada, Shawinigan, QC, 2009, personal communication).

No changes are suggested to the manner in which fire spread rates for the FBP System fuel type M-2 is calculated as a result of formal recognition of a D-2 fuel type and the BUI $\geq 70$ threshold criteria for surface fire spread. However, users may wish to consider applying equation [2] only for cases where $\mathrm{PH}>10$.

\section{D-2 Fuel Type Descriptive Name and Characteristics}

For the sake of consistency, what descriptive name should be given to a D-2 FBP System fuel type? To date, it has been termed "aspen, green" (Beaver 2006), "deciduous leafed out" (de Groot et al. 2007), "aspen - green” (Hall et al. 2008), "summer deciduous" (de Groot et al. 2009), "aspen, summer condition" (de Groot et al. 2009), and "leafed-out aspen" (Wotton et al. 2009). The name "leafed aspen" (i.e., summer) logically follows from FBP System fuel type D-1 - leafless aspen for spring and fall fire seasons. However, to be as consistent as possible with fuel type D-1 and the two boreal mixedwood fuel types M-1 and M-2, it is recommended that green aspen be used as the descriptive name for the D-2 fuel type from now on.

Young trembling aspen stands are not particularly flammable, but woody surface fuels do gradually increase with age as stands break up as a result of overstory tree mortality (Lee et al. 1997, Hély et al. 2000). Woody fuel accumulations in aspen stands have increased in recent years in central Alberta (Fig. 6) and central Saskatchewan as a result of dieback and mortality because of insect defoliation and fungal pathogens, drought, and thaw-free events (Hogg et al. 2008). This has substantially altered the live-dead ratio of the surface fuelbeds in decadent aspen stands and thereby increased the likelihood of fire spread following green-up in the summer (B. Irving, University of Alberta, Edmonton, AB, 2009, personal communication ), similar to what has been observed in spruce budworm (Choristoneura fumiferana [Clemens])-killed balsam fir (Abies balsamea (L.) Mill.) stands in northeastern Ontario (Stocks 1987).

What kind of trembling aspen fuel complex would the D-2 fuel type represent and how should it be described? Wotton et al. (2009) have pointed out that the D-1 fuel type as it presently exists in the FBP System is not intended for mature and overmature trembling aspen stands exhibiting large quantities of dead and downed woody material such as occurred during the 2001 Chisholm Fire (Ember Research Services Ltd. 2003a, 2003b). This is because the vast majority of the experimental fires used in the development of the D-1 fuel type fire behavior models involved minimal quantities of dead and downed woody fuels (Alexander and Sando 1989, Quintilio et al. 1991).

Given the current description for the D-1 fuel type and what it is intended to represent, and in turn what the D-2 fuel type should represent, a suggested description for the D-2 fuel type is given in Box 1 that is consistent with what is presented in the principal technical publication on the FBP System (Forestry Canada Fire Danger Group 1992). The corresponding details for fuel type D-2 in terms of the fuel type characteristics contained in Table 3 of Forestry Canada Fire Danger Group (1992) are as follows:

- Forest floor and organic layer - Continuous matted leaf litter; shallow, uncompacted organic layer. 


\section{Box 1 - Detailed Written Description of FBP System Fuel Type D-2 (Green Aspen)}

Fuel type D-2 (green aspen): This fuel type is characterized by healthy and pure, semimature trembling aspen (Populus tremuloides Michx.) stands during the summer fire season (i.e., following "green-up" or full flushing of the overstory canopy and understory vegetation in late spring or early summer until leaf senescence and drop in the fall). A conifer understory is noticeably absent, but a well-developed medium to tall shrub layer is typically present. Dead and down roundwood fuels are a minor component of the fuel complex. A lush layer of herbaceous plants (i.e., herbs, forbs, and grasses) exists on the ground surface and coupled with the presence of shrubs, the existence of this "green surface fuel effect" with its very high fuel moisture contents serves to dampen surface fire spread potential. The shading from the overstory and understory vegetation markedly reduces solar radiation at the forest floor level. Relative humidity also increases and in-stand wind speed decreases.

- Surface and ladder fuels - Moderately dense, medium to tall shrubs and herbaceous layers in full "green" state; absent conifer understory; sparse, dead down woody fuels.

- Stand structure and composition - Healthy and moderately well-stocked trembling aspen stands; semimature; leafed out stage (i.e., summer).

Neither the D-1 nor D-2 fuel types of the FBP System should be used in situations involving trembling aspen with substantial quantities of understory white spruce (Picea glauca (Moench) Voss) or balsam fir. FBP System fuel types M-1 and M-2 should still be used in such cases with varying $\mathrm{PC}$ values of up to 50 or possibly higher.

\section{Suggestions for Future Action}

What should be done next? Additional information in the form of a relatively few well-documented wildfires and prescribed fires would probably do more to improve our understanding of fire spread in northern hardwood stands in summer than analyzing a mass of individual fire report data and associated maps. A concerted effort should be made during the next few fire seasons to evaluate the general performance of equation [3] and the BUI threshold criteria by more closely monitoring wildfire activity during the summer months as the opportunities present themselves (Alexander and Taylor 2010). Given the inherent spatial variability in summertime rainfall on FWI System components (Lawson and Armitage 2008), the focus should be on wildfires that are within a very short distance of weather stations $(<1 \mathrm{~km})$ in order to avoid any uncertainties with regard to knowing what the rainfall history was at the fire site. There may also be occasions to make similar observations on operational prescribed fires (Alexander 2006). Finally, it may be useful to carefully reexamine particular incidents in the past in order to "mine" useful data and information (Alexander 2005).

Furthermore, perhaps some organization will step forward and support a formal experimental burning project (Alexander and Quintilio 1990) in mid-summer in one or more specific trembling aspen fuel types or other deciduous forest stands. Other than the field research carried out by the CFS, past interest in experimental burning in hardwoods in Canada to generate fire behavior data has been quite limited, although there have a been a few exceptions (e.g., Burton and Sloane 1958, Sinclair 1962, Smith and James 1978). The experimental plots need not be large - from $10 \times 10 \mathrm{~m}$ up to $30 \times 30 \mathrm{~m}$ should suffice. Artificially inducing certain BUI levels by excluding rainfall will undoubtedly be needed (Otway et al. 2007a, 2007b). The potential for escape fires would be minimal, especially if the experimental study area were surrounded by agricultural or crop lands. The need to conduct a series of experimental fires in decadent as well as mature and overmature trembling aspen stands (Fig. 6) over a range of burning conditions as expressed by the FWI System during the spring, summer and fall seasons is sorely needed according to other fire researchers and many fire managers alike (M. Parisien, Canadian Forest Service and B. Bereska, Wildfire Consulting Ltd., Edmonton, AB, 2009, personal communication). The potential benefits to safety awareness amongst firefighters and members of the general public would be enormous (Alexander et al. 2007), but especially in the aspen parklands of the Prairie Provinces.

Data on fire behavior in relation to fuel and weather conditions from wildfires, prescribed fires, and/or experimental fires are needed not only for the future development of the FBP System but also for fuels management purposes. (Alexander 2000). For example, in determining the effectiveness of various types of aspen fuelbreaks under different burning conditions as a means of protecting values-at-risk in the wildland-urban interface and in mitigating the potential for large fires (Johnson 1975; Fechner and Barrows 1976; Hirsch et al. 2001, 2004) as well as using aspen stands in summer as fireguards for prescribed burning in adjacent fuel types or minimizing escape fire potential (Wright and Bailey 1982).

Additional analysis of the entire CFS 2-minute test fire database (Paul 1969, Simard 1970) will no doubt provide greater insight into the conditions required for surface fire spread in boreal hardwood stands following full green-up that can be compared against observations from larger-scale fire occurrences such as experimental fires, prescribed fires, and wildfires. In the meantime, the present paper represents a digest of currently available knowledge on the topic of surface fire spread potential in trembling aspen stands during the summer fire season as it pertains to the boreal region of Canada. Hopefully it will inspire others to carry out field studies that will lead to improvements in our understanding on the subject.

\section{Acknowledgements}

The data associated with Fig. 4 was kindly provided by Richard Carr (CFS). The feedback of Brad Armitage (Ember Research Services Ltd.), Al Beaver (Victorian Department of Sustainability and Environment), Bill Bereska (Wildfire Consulting Ltd.), Bill Droog (Ontario Ministry of Natural Resources), Dave Finn (Alberta Sustainable Resource Development), Brad Hawkes (CFS), Mark Heathcott (Parks Canada), Kato Howard (Alaska Fire Service), Barry Irving (University of Alberta), Jill Johnstone (University of Saskatchewan), Nathalie Lavoie (Quebec Ministère des Ressources Naturelles et de la Faune), Bruce Lawson (Ember Research Services Ltd.), Glen Longpre (Saskatchewan Parks Service), Marc Parisien (CFS), Grant Pearce (New Zealand 
Scion Rural Fire Research Group), Randi Smith (New Brunswick Department of Natural Resources), Michel Theriault (Parks Canada), and Terry Van Nest on an earlier draft of this article are duly acknowledged. The comments of two anonymous reviewers greatly improved the final product. I would also like to thank Brenda Laishley and Sue Mayer (CFS), Nick Nimchuk and Liz Summers (Alberta Sustainable Resource Development), Miguel Cruz (CSIRO Bushfire Dynamics and Applications), and Jen Beverly (CFS) for their assistance in the preparation of this article.

\section{References}

Alexander, M.E. 1982. Fire behavior in aspen slash fuels as related to the Canadian Fire Weather Index. Can. J. For. Res. 12: 1028-1029. Alexander, M.E. 2000. Fire behavior knowledge gaps (\& research needs) pertaining to ecosystem management. Invited paper presented at the Workshop on Integrated Resource Management in Ecosystems Dominated by High Intensity Fire: Challenges, Tools and Solutions, 8-10 November 2000, Edmonton, AB. 6 p. Available at http://fire.feric.ca/other/FireBehaviorKnowledgeGaps. htm [Accessed 10 April 2009].

Alexander, M.E. 2004. An overview of systems for rating fire danger and predicting fire behavior used in Canada. Invited presentation at the S-590 Advanced Fire Behavior Interpretation Course, National Advanced Resource Technology Center, Marana, AZ. Available at http://depts.washington.edu/nwfire/project.php?projec$\mathrm{tID}=536 \&$ microweb $=0$ [Accessed 1 June 2009].

Alexander, M.E. 2005. Wildland fire and drought: searching for practical solutions. Contributed presentation at the $19^{\text {th }}$ Annual Meeting of the Interior West Fire Council and $6^{\text {th }}$ Symposium on Fire and Forest Meteorology of the American Meteorological Society, 25-27 October 2005, Canmore, AB. Available at http://fire.feric.ca/Conference/DroughtAndWildlandFireFor PracticalSolutions_files/frame.htm

[Accessed 9 December 2009].

Alexander, M.E. 2006. Prescribed burn documentation and fire danger ratings: a case study. In D.X. Viegas (ed.). Proceedings of 5th International Conference on Forest Fire Research, 27-30 November 2006, Figueira da Foz, Portugal. Elsevier B.V., Amsterdam, The Netherlands. CD-ROM. 12 p.

Alexander, M.E. and F.V. Cole. 1995. Predicting and interpreting fire intensities in Alaskan black spruce forests using the Canadian system of fire danger rating. In Managing Forests to Meet People's Needs - Proceedings of 1994 Society of American Foresters/Canadian Institute of. Forestry Convention, 18-22 September 1994, Anchorage, AK. pp. 185-192. Soc. Am. For., Bethesda, MD. SAF Publ. 95-02.

Alexander, M.E. and R.A. Lanoville. 2004. The International Crown Fire Modelling Experiment fuel treatment trials. In R.T. Engstrom, K.E.M. Galley and W.J. de Groot (eds.). Proceedings of the $22^{\text {nd }}$ Tall Timbers Fire Ecology Conference: Fire in Temperate, Boreal, and Montane Ecosystems, 15-18 October 2001, Kananaskis Village, AB. p. 222. Tall Timbers Res. Stn., Tallahassee, FL.

Alexander, M.E. and M.E. Maffey. 1992-93. Predicting fire behavior in Canada's aspen forests. Fire Manage. Notes 53-54(1): 10-13. Alexander, M.E., R.W. Mutch and K.M. Davis. 2007. Wildland fires: dangers and survival. In P.S. Auerbach (ed.). Wilderness Medicine. 5th ed. pp. 286-335. Mosby, Philadelphia, PA.

Alexander, M.E. and D. Quintilio. 1990. Perspectives on experimental fires in Canadian forestry research. Math. Comput. Model. 13(12): 17-26.

Alexander, M.E. and R.W. Sando. 1989. Fire behavior and effects in aspen-northern hardwood stands. In D.C. MacIver, H. Auld and R. Whitewood (eds.). Proceedings of $10^{\text {th }}$ Conference on Fire and Forest Meteorology, 17-21 April 1989, Ottawa, ON. pp. 263-274. For. Can. and Environ. Can., Ottawa, ON.
Alexander, M.E. and S.W. Taylor. 2010. Wildland fire behavior case studies and the 1938 Honey Fire controversy. Fire Manage. Today 70(1): 15-25.

Amiro, B.D., B.J. Stocks, M.E. Alexander, M.D. Flannigan and B.M. Wotton. 2001. Fire, climate change, carbon and fuel management in the Canadian boreal forest. Int. J. Wildland Fire 10: 405-413. Andrews, P.L., C.D. Bevins and R.C. Seli. 2008. BehavePlus fire modeling system, version 4.0: User's guide. USDA For. Serv., Rocky Mt. Res. Stn., Fort Collins, CO. Gen. Tech. Rep. RMRS-GTR106WWW Revised. 116 p.

Beall, H.W. 1934. The penetration of rainfall through hardwood and softwood forest canopy. Ecology 15: 412-415.

Beaver, A. 2006. Wildfire protection - forest protection (What does it really mean?). Dep. Community Serv., Whitehorse, YT. 11 p. Available at http:/www.community.gov.yk.ca/pdf/What_is_fire protection.pdf [Accessed 12 November 2009].

Beverly J.L., E.P.K. Herd and J.C.R. Conner. 2009. Modeling fire susceptibility in west central Alberta, Canada. For. Ecol. Manage. 258: 1465-1478.

Beverly, J.L. and B.M. Wotton. 2007. Modelling the probability of sustained flaming: predictive value of Fire Weather Index components compared with observations of site weather and fuel moisture conditions. Int. J. Wildland Fire 16: 161-173.

Brown, A.A. and K.P. Davis. 1973. Forest fire: control and use. $2^{\text {nd }}$ ed. McGraw-Hill, New York, NY. 686 p.

Brown, J.K., G.D. Booth and D.G. Simmerman. 1989. Seasonal change in live fuel moisture of understory plants in western U.S. aspen. In D.C. MacIver, H. Auld and R. Whitewood (eds.). Proceedings of $10^{\text {th }}$ Conference on Fire and Forest Meteorology, 17-21 April 1989, Ottawa, ON. pp. 406-412. For. Can. and Environ. Can., Ottawa, ON.

Brown, J.K. and D.G. Simmerman. 1986. Appraising fuels and flammability in western aspen: a prescribed fire guide. USDA For. Serv., Intermt. Res. Stn., Ogden, UT. Gen. Tech. Rep. INT-205. 48 p. Burton, D.H. and N.H. Sloane. 1958. Progress report on prescribed burning in the hard maple-yellow birch cover type in Ontario. Ont. Dep. Lands For., Div. Res., Maple, ON. Sec. Rep. (For.) 25. 17 p.

Butler, J. 1997. Wildfire loose: the week Maine burned. 3rd ed. Down East Books, Camden, ME. 278 p.

Byram, G.M. and G.M. Jemison. 1943. Solar radiation and forest fuel moisture. J. Agric. Res. 67: 149-176.

Cumming, S.G. 2001. Forest type and wildfire in the Alberta boreal mixedwood: what do fires burn? Ecol. Appl. 11: 97-110.

DeByle, N.V., C.D. Bevins and W.C. Fischer. 1987. Wildfire occurrence in aspen in the interior western United States. West. J. Appl. For. 2: 73-76.

de Groot, W.J., R. Landry, W.A. Kurz, K.R. Anderson, P. Englefield, R.H. Fraser, R.J. Hall, E. Banfield, D.A. Raymond, V. Decker, T.J. Lynham and J.M. Prichard. 2007. Estimating direct carbon emissions from Canadian wildland fires. Int. J. Wildland Fire 16: 593-606.

de Groot, W.J., J.M. Pritchard and T.J. Lynham. 2009. Forest floor fuel consumption and carbon emissions in Canadian boreal forest fires. Can. J. For. Res. 39: 367-382.

Dickinson, M.B. and E.A. Johnson. 2003. Surface fire extinction in mixedwood boreal forest fuels. Univ. Alta., Sustain. For. Manage. Network, Edmonton, AB. Proj. Rep. 2004-1. 10 p.

Dunne, T. and L.B. Leopold. 1978. Water in environmental planning. W.H. Freeman Company, San Francisco, CA. 818 p.

Ember Research Services Ltd. 2003a. Aspen stands stop fires, don't they? Foothills Model For., Hinton, AB. Chisholm/Dogrib Fire Res. Initiative Quicknote 3.2 p.

Ember Research Services Ltd. 2003b. Fire behaviour in immature and mature aspen stands under severe spring burning conditions: does fire history matter? Foothills Model For., Hinton, AB. Chisholm/Dogrib Fire Res. Initiative Rep. 1. 94 p. 
Fechner, G.H. and J.S. Barrows. 1976. Aspen stands as wildfire fuel breaks. USDA For. Serv., Rocky Mt. For. Range Exp. Stn., Fort Collins, CO. Eisenhower Consortium Bull. 4. 26 p.

Forestry Canada Fire Danger Group. 1992. Development and structure of the Canadian Forest Fire Behavior Prediction System. For. Can., Ottawa, ON. Inf. Rep. ST-X-3. 63 p.

Frederick, R.H. 1961. A study of the effect of tree leaves on wind movement. Mon. Weather Rev. 89: 39-44.

Haines, D.A., V.J. Johnson and W.A. Main. 1975. Wildfire atlas of the northeastern and north central States. USDA For. Serv., North Cent. For. Exp. Stn., St. Paul, MN. Gen. Tech. Rep. NC-16. 25 p.

Haines, D.A., V.J. Johnson and W.A. Main. 1976. An assessment of three measures of long-term moisture deficiency before critical fire periods. USDA For. Serv., North Cent. For. Exp. Stn., St. Paul, MN. Res. Pap. NC-131. 13 p.

Haines, D.A., W.A. Main and J.S. Crosby. 1973. Forest fires in Missouri. USDA For. Serv., North Cent. For. Exp. Stn., St. Paul, MN. Res. Pap. NC-87. 18 p.

Haines, D.A., W.A. Main and V.J. Johnson. 1970. Relation between the national fire danger spread component and fire activity in the Lake States. USDA For. Serv., North Cent. For. Exp. Stn., St. Paul, MN. Res. Pap. NC-41. 8 p.

Haines, D.A., W.A. Main and E.F. McNamara. 1978. Forest fires in Pennsylvania. USDA For. Serv., North Cent. For. Exp. Stn., St. Paul, MN. Res. Pap. NC-158. 20 p.

Haines, D.A., W.A. Main and A.J. Simard. 1986. Fire-danger rating and observed wildfire behavior in the northeastern United States. USDA For. Serv., North Cent. For. Exp. Stn., St. Paul, MN. Res. Pap. NC-274. 23 p.

Haines, D.A. and R.W. Sando. 1969. Climatic conditions preceding historically great fires in the North Central Region. USDA For. Serv., North Cent. For. Exp. Stn., St. Paul, MN. Res. Pap. NC-34. 19 p.

Hall, R.J., J.T. Freeburn, W.J. de Groot, J.M. Pritchard, T.J. Lynham and R. Landry. 2008. Remote sensing of burn severity: experience from western Canada boreal fires. Int. J. Wildland Fire 17: 476-489.

Hély, C., Y. Bergeron and M. Flannigan. 2000. Effects of stand composition on fire hazard in mixed-wood Canadian boreal forest. J. Veg. Sci. 11: 813-824.

Hély, C., M. Flannigan, Y. Bergeron and D. McRae. 2001. Role of vegetation and weather on fire behavior in the Canadian mixedwood boreal forest using two fire behavior prediction systems. Can. J. For. Res. 31: 430-441.

Hinzman, L.D., M. Fukuda, D.V. Sandberg, F.S. Chapin III and D. Dash. 2003. FROSTFIRE: an experimental approach to predicting the climate feedbacks from the changing boreal fire regime. J. Geophys. Res. 108(D1), 8153, doi:10.1029/2001JD000415.

Hirsch, K., V. Kafka and B. Todd. 2004. Using forest management techniques to alter forest fuels and reduce wildfire size: an exploratory analysis. In R.T. Engstrom, K.E.M. Galley and W.J. de Groot (eds.). Proceedings of the 22nd Tall Timbers Fire Ecology Conference: fire in temperate, boreal and montane ecosystems, 15-18 October 2001, Kananaskis Village, AB. pp. 175-184. Tall Timbers Res. Stn., Tallahassee, FL.

Hirsch, K., V. Kafka, C. Tymstra, R. McAlpine, B. Hawkes, H. Stegehuis, S. Quintilio, S. Gauthier and K. Peck. 2001. Fire-smart forest management: a pragmatic approach to sustainable forest management. For. Chron. 77: 357-363.

Hogg, E.H., J.P. Brandt and M. Michaelian. 2008. Impacts of a regional drought on the productivity, dieback, and biomass of western Canadian aspen forests. Can. J. For. Res. 38: 1373-1384.

Jemison, G.M. and A.W. Lindenmuth and J.J. Keetch. 1949. Forest fire-danger measurement in the eastern United States. U.S. Dep. Agric., Washington, DC. Agric. Handb. 1.68 p.

Johnson, E.A. 1992. Fire and vegetation dynamics: studies from the North American boreal forest. Cambridge University Press, Cambridge, UK $129 \mathrm{p}$.
Johnson, V.J. 1975. Hardwood fuel-breaks for northeastern United States. J. For. 73: 588-589.

Juday, G.P. 1985. The Rosie Creek Fire. Agroborealis 17(1): 11-20. Kiil, A.D. and J.E. Grigel. 1969. The May 1968 forest conflagrations in central Alberta - a review of fire weather, fuels and fire behavior. Can. Dep. Fish. For., For. Branch, For. Res. Lab., Edmonton, AB. Inf. Rep. A-X-24. 36 p.

Kiil, A.D. and J.S. Mactavish. 1962. Forest fire danger tables: District of Mackenzie, Northwest Territories. Can. Dep. For., For. Res. Branch, Ottawa, ON. 11 p. [reprinted in 1967 as Can. Dep. For. Rural Develop. For. Branch Publ. 1197]

Kiil, A.D., R.S. Miyagawa and D. Quintilio. 1977. Calibration and performance of the Canadian Fire Weather Index in Alberta. Environ. Can., Can. For. Serv., North. For. Res. Cent., Edmonton, AB. Inf. Rep. NOR-X-173. 45 p.

Kiil, A.D. and D. Quintilio. 1969. Occurrence and behavior of forest fires related to fire danger rating in Alberta, 1957-1963. Can. Dep. Fish. For., Can. For. Serv., For. Res. Lab., Calgary, AB. Inf. Rep. A-X$25.20 \mathrm{p}$.

Krawchuk, M.A., S.G. Cumming, M.D. Flannigan and R.W. Wein. 2006. Biotic and abiotic regulation of lightning fire initiation in the mixedwood boreal forest. Ecology 87: 458-468.

Lawson, B.D.; Armitage, O.B. 2008. Weather guide for the Canadian Forest Fire Danger Rating System. Natural Resources Canada, Canadian Forest Service, Northern Forestry Centre, Edmonton, AB. $73 \mathrm{p}$.

Lawson, B.D., B.J. Stocks, M.E. Alexander and C.E. Van Wagner. 1985. A system for predicting fire behavior in Canadian forests. In L.R. Donoghue and R.E. Martin (eds.). Proceedings of the Eighth Conference on Fire and Forest Meteorology, 29 April - 2 May 1985, Detroit, MI. pp. 6-16. Soc. Am. For., Bethesda, MD. SAF Publ. 85-04.

Lee, B.S., M.E. Alexander, B.C. Hawkes, T.J. Lynham, B.J. Stocks and P. Englefield. 2002. Information systems in support of wildland fire management decision making in Canada. Comput. Electron. Agric. 37: 185-198.

Lee, P.C., S. Crites, M. Nietfeld, H. Van Nguyen and J.B. Stelfox. 1997. Characteristics and origins of deadwood material in aspendominated boreal forests. Ecol. Appl. 7: 691-701.

Loomis, R.M. and P.J. Roussopoulos. 1978. Estimating aspen crown fuels in northeastern Minnesota. USDA For. Serv., North Cent. For. Exp. Stn., St. Paul, MN. Res. Pap. NC-156. 6 p.

Loomis, R.M., P.J. Roussopoulos and R.W. Blank. 1979. Summer moisture contents of understory vegetation in northeastern Minnesota. USDA For. Serv., North Cent. For. Exp. Stn., St. Paul, MN. Res. Pap. NC-179. 7 p.

Marston, R.B. 1956. Air movement under an aspen forest and on adjacent opening. J. For. 54: 468-469.

Otway, S.G. 2005. Aspen forest duff moisture depletion and ground fire potential. Univ. Alta., Edmonton, AB. M.Sc. Thesis. 191 p.

Otway, S.G., E.W. Bork, K.R. Anderson and M.E. Alexander. 2007a. Predicting the probability of sustained smouldering combustion in trembling aspen duff. Int. J. Wildland Fire 16: 690-701.

Otway, S.G., E.W. Bork, K.R. Anderson and M.E. Alexander. 2007b. Relating changes in duff moisture to the Canadian Forest Fire Weather Index System in Populus tremuloides stands in Elk Island National Park. Can. J. For. Res. 37: 1987-1998.

Parisien, M.-A., D.R. Júnior and V.G. Kafka. 2007. Comparing landscape-based decision rules for placement of fuel treatments in the boreal mixedwood of western Canada. Int. J. Wildland Fire 16: 664-672.

Parisien, M.-A., V. Kafka, N. Flynn, K.G. Hirsch, J.B. Todd and M.D. Flannigan. 2005a. Fire behavior potential in central Saskatchewan under predicted climate change. Prairie Adapt. Res. Collaborat., Regina, SK. PARC Summ. Doc. 05-01. 12 p.

Parisien, M.-A., V. Kafka, K.G. Hirsch, J.B. Todd, S.G. Lavoie and P.D. Maczek. 2005b. Mapping wildfire susceptibility with the 
BURN-P3 simulation model. Nat. Resour. Can., Can. For. Serv., North. For. Cent., Edmonton, AB. Inf. Rep. NOR-X-405. 36 p.

Paul, P.M. 1969. Field practices in forest fire danger rating. Can. Dep. Fish. For., Can. For. Serv., For. Fire Res. Instit., Ottawa, ON. Inf. Rep. FF-X-20. 39 p.

Quintilio, D., M.E. Alexander and R.L. Ponto. 1991. Spring fires in a semimature trembling aspen stand in central Alberta. For. Can., North. For. Cent., Edmonton, AB. Inf. Rep. NOR-X-323. 30 p.

Quintilio, D., B.D. Lawson, S. Walkinshaw and T. Van Nest. 2001. Final documentation report - Chisholm Fire (LWF-063). Alta. Sustainable Resour. Develop., For. Prot. Div., Edmonton, AB. Publ. I/036. n.p.

Rorig, M.L., S.A. Ferguson and D.V. Sandberg. 2003. Fire weather indexes and fuel condition in Alaska. In K.E.M. Galley, R.C. Klinger and N.G. Sugihara (eds.). Proceedings of Fire Conference 2000: The First National Congress on Fire Ecology, Prevention, and Management, 27 November - 1 December 2000, San Diego, CA. pp. 202210. Tall Timbers Res. Stn., Tallahassee, FL. Misc. Publ. 13.

Rothermel, R.C. 1983. How to predict the spread and intensity of forest and range fires. USDA For. Serv., Intermt. For. Range Exp. Stn., Ogden, UT. Gen. Tech. Rep. INT-143. 161 p.

Rowe, J.S. 1972. Forest regions of Canada. Environ. Can.., Can. For. Serv., Ottawa, ON. Publ. 1300. 172 p.

Sayn-Wittgenstein, L. 1978. Recognition of tree species on aerial photographs. Environ. Can., Can. For. Serv., For. Manage. Instit., Ottawa, ON Inf. Rep. FMR-X-118. 97 p.

Simard, A.J. 1970. Reference manual and summary of test fire, fuel moisture, and weather observations made by forest fire researchers between 1931 and 1961. Can. Dep. Fish. For., Can. For. Serv., For. Fire Res. Instit., Ottawa, ON. Inf. Rep. FF-X-25. 113 p.

Simard, A.J., J.E. Eenigenburg and W.A. Main. 1989. A weatherbased fire season model. In D.C. MacIver, H. Auld and R. Whitewood (eds.). Proceedings of $10^{\text {th }}$ Conference on Fire and Forest Meteorology, 17-21 April 1989, Ottawa, ON. pp. 213-224. For. Can. and Environ. Can., Ottawa, ON.

Sinclair, G.A. 1962. Progress report of prescribed burning in hardwood stands. Ont. Dep. Lands For., Res. Branch, Maple, ON. Sec. Rep. (For.) 45. 22 p.

Smith, D.W. and T.D. James. 1978. Characteristics of prescribed burns and resultant short-term environmental changes in Populus tremuloides woodland in southern Ontario. Can. J. Bot. 56: 1782-1791.

Stickel, P.W. 1931. The measurement and interpretation of forest fire-weather in the western Adirondacks. Syracuse Univ., New York State Coll. For., Syracuse, NY. Tech Publ. 34.115 p.

Stocks, B.J. 1987. Fire potential in spruce budworm-damaged forests of Ontario. For. Chron. 63: 8-14.

Stocks, B.J. 1988. Forest fire close to home: Terrace Bay Fire \#7/86. In W.C. Fischer and S.F. Arno (comps.). Protecting People and Homes from Wildfire in the Interior West: Proceedings of Symposium and Workshop, 6-8 October 1987, Missoula, MT. pp. 147-156. USDA For. Serv., Intermt. Res. Stn., Ogden, UT. Gen. Tech. Rep. INT-251.

Stocks, B.J., M.E. Alexander and R.A. Lanoville. 2004. Overview of the International Crown Fire Modelling Experiment (ICFME). Can. J. For. Res. 34: 1543-1547.

Taylor, S.W., R.G. Pike and M.E. Alexander. 1997. Field guide to the Canadian Forest Fire Behavior Prediction (FBP) System Nat. Resour. Can., Can. For. Serv., North. For. Cent., Edmonton, AB. Spec. Rep. 11.60 p.

Tucker, R.E. and J.M. Jarvis. 1967. Prescribed burning in a white spruce - trembling aspen stand in Manitoba. Pulp Pap. Mag. Can. Woodlands Rev. 66: 333-335.

Tymstra, C., R.W. Bryce, B.M. Wotton, S.W. Taylor and O.B. Armitage. 2009. Development and structure of Prometheus: the
Canadian wildland fire growth simulation model. Nat. Resour. Can., Can. For. Serv., North. For. Cent., Edmonton, AB. Inf. Rep. NOR-X417. $88 \mathrm{p}$.

Tymstra, C., D. Wang and M.-P. Rogeau. 2005. Alberta wildfire regime analysis. Alta. Dep. Sustainable Resour. Develop., For. Prot. Div., Wildfire Policy Business Plann. Branch, Edmonton, AB. Wildfire Sci. Tech. Rep. PFFC-01-05. n.p.

Van Wagner, C.E. 1967. Seasonal variation in moisture content of eastern Canadian tree foliage and possible effect on crown fires. Can. Dep. For. Rural Develop., For. Branch, Ottawa, ON. Dep. Publ. 1204 $15 \mathrm{p}$.

Van Wagner, C.E. 1969. Combined effect of sun and wind on surface temperature of litter. Can. Dep. Fish. For., For. Branch, Petawawa For. Exp. Stn., Chalk River, ON. Inf. Rep. PS-X-10. 7 p.

Van Wagner, C.E. 1970. An index to estimate the current moisture content of the forest floor. Can. Dep. Fish. For., Can. For. Serv., Ottawa, ON. Publ. 1288. 23 p.

Van Wagner, C.E. 1975. A comparison of the Canadian and American forest fire danger rating systems. Environ. Can., Can. For. Serv., Petawawa For. Exp. Stn., Chalk River, ON. Inf. Rep. PS-X-59. 22 p. Van Wagner, C.E. 1977. Conditions for the start and spread of crown fire. Can. J. For. Res. 7: 23-34.

Van Wagner, C.E. 1979. Meteorology and forest fire management. In Proceedings of the Symposium on Forest Meteorology, 21-25 August 1978, Ottawa, ON. pp. 102-107. World Meteor. Organ., Geneva, Switzerland. WMO Publ. 527.

Van Wagner, C.E. 1983. Fire behaviour in northern conifer forests and shrublands. In R.W. Wein and D.A. Maclean (eds.). SCOPE 18: The Role of Fire in Northern Circumpolar Ecosystems. pp. 65-80. John Wiley \& Sons, Chichester, England.

Van Wagner, C.E. 1985. Fire behavior modelling - how to blend art and science. In L.R. Donoghue and R.E. Martin (eds.). Proceedings of the Eighth Conference on Fire and Forest Meteorology, 29 April 2 May 1985, Detroit, MI. pp. 3-5. Soc. Am. For., Bethesda, MD. SAF Publ. 85-04.

Van Wagner, C.E. 1987. Development and structure of the Canadian Forest Fire Weather Index System. Environ. Can., Can. For. Serv., Ottawa, ON. For. Tech. Rep. 35. 37 p.

Weil, R.R. 2003. Getting to know a catena: a field exercise for introductory soil science. J. Nat. Resour. Life Sci. Educ. 32: 1-4.

Wein, R.W. and J.M. Moore. 1977. Fire history and rotations in the New Brunswick Acadian Forest. Can. J. For. Res. 7: 285-294.

Williamson, T.B., D.T. Price, J.L. Beverly, P.M. Bothwell, B. Frenkel, J. Park and M.N. Patriquin. 2008. Assessing potential biophysical and socioeconomic impacts of climate change on forestbased communities: a methodological case study. Nat. Resour. Can., Can. For. Serv., North. For. Cent., Edmonton, AB. Inf. Rep. NOR-X415E. 136 p.

Wotton, B.M., M.E. Alexander and S.W. Taylor. 2009. Updates and revisions to the 1992 Canadian Forest Fire Behavior Prediction System. Nat. Resour. Can., Can. For. Serv., Great Lakes For. Cent., Sault Ste. Marie, ON. Inf. Rep. GLC-X-10. 45 p.

Wotton, B.M. and J.L. Beverly. 2007. Stand-specific litter moisture content calibrations for the Canadian Fine Fuel Moisture Code. Int. J. Wildland Fire 16: 463-472.

Wright, H.A. and A.W. Bailey. 1982. Fire ecology, United States and southern Canada. John Wiley \& Sons, New York, NY. 501 p.

Wright, J.G., and H.W. Beall. 1934. Seasonal vegetation and forest fire hazard. Pulp Pap. Mag. Can. 35(5): 259-261.

Wright, J.G. and H.W. Beall. 1938. Preliminary improved forestfire hazard tables for eastern Canada. Can. Dep. Mines Resour., Lands, Parks For. Branch, Dom. For. Serv., Ottawa, ON. For.-Fire Res. Note $5.51 \mathrm{p}$. 